DOI https://doi.org/10.30525/978-9934-26-148-0-15

\title{
ON CONSIDERATION OF THE DRAFT LAW BY THE VERKHOVNA RADA OF UKRAINE WITHOUT DISCUSSION AND VOTING FOR EACH PROPOSAL TO IT
}

\author{
Zozulia O. I. \\ Doctor of Law, Associate Professor, \\ Head of Scientific Sector of Comparative Constitutional and Municipal Law \\ Scientific Research Institute of State Building and Local Government \\ of the National Academy of Legal Sciences of Ukraine \\ Zozulia I. V. \\ Doctor of Law, Professor, \\ Professor at Department of Law Enforcement and Police \\ Kharkiv National University of Internal Affairs \\ Kharkiv, Ukraine
}

The problem of «legislative spam», in particular the abuse of the right of people's deputies of Ukraine to amend amendments to bills, negatively affects the efficiency of the Verkhovna Rada of Ukraine, often significantly complicating and even blocking the adoption of socially important laws. At the same time, the political and other expediency of adopting the relevant laws cannot outweigh the need for strict observance of the constitutional procedure for consideration draft laws and the right of legislative initiative, which is an integral condition for the constitutionality of the laws of Ukraine. In view of this, we consider the issues of constitutionality of consideration of the bill without discussion and voting for each proposal to it to be relevant.

First of all, we note that Part 1 of Article 93 of the Constitution of Ukraine of 28.06.1996 [1] does not directly disclose the content of the right of legislative initiative, in particular whether it is limited to the right to submit bills to parliament, or also includes the right to submit to their proposals and amendments.

In accordance with Part 5 of Article 89 of the Rules of Procedure of the Verkhovna Rada of Ukraine of 10.02.2010 [2] the right of legislative initiative is exercised by submitting to the Verkhovna Rada of Ukraine draft laws, resolutions and other acts, proposals and amendments to bills. Compliance with the norms of the Rules of Procedure of the Verkhovna Rada of Ukraine is not decisive for assessing the constitutionality of the procedure for consideration and adoption of a law. At the same time, the approach 
set out in the Rules of Procedure of the Verkhovna Rada of Ukraine to the understanding of the content of the right of legislative initiative and the methods of its implementation reflects the established constitutional practice.

In the scientific literature (Victor Kravchenko [3], Tetiana Topolyanska [4], etc.) the content of the right of legislative initiative also includes the right to submit not only a new bill, but also proposals and amendments to it. According to the judge of the Constitutional Court of Ukraine Sergii Sas [5], the purpose of the right to submit proposals and amendments is «comprehensive discussion and consideration of different approaches to the adoption of quality laws, saving plenary time of parliamentary sessions, improving the efficiency of its work».

As the Constitutional Court of Ukraine directly states in its Decision of 28.02.2018 [5], the constitutional right of legislative initiative "directly corresponds to the constitutional obligation of the parliament to consider the submitted draft laws, proposals to them, as well as to adopt or reject them». In addition, «the procedure for considering the draft law is implemented... at certain stages of the legislative process - by making proposals to it». Thus, the Constitutional Court of Ukraine clearly shares the position that the right to make proposals to bills is a component of the constitutional right of legislative initiative.

Judge of the Constitutional Court of Ukraine Mykhailo Gultay [5] draws attention to the unfoundedness of the Constitutional Court of Ukraine in its conclusion that the exercise of the right of legislative initiative requires mandatory consideration of submitted bills and proposals by parliament. The Constitutional Court of Ukraine in its Decision of 28.02.2018 really did not provide a proper argumentation of this position, which at the same time does not indicate its erroneousness.

The Constitution of Ukraine is an integral, systematic act of the constituent power. Therefore, the constitutional right to submit a bill, amendments and proposals to the parliament for consideration is systematically connected with the authority of the Verkhovna Rada of Ukraine to adopt laws. This allows us to speak about the obligation of the parliament to consider bills, amendments and proposals to them in the framework of the implementation of the right of legislative initiative. In particular, as noted by Judge of the Constitutional Court of Ukraine Oleksandr Litvinov [5], «the obligation to consider draft laws and make appropriate decisions follows from the constitutional status of the Verkhovna Rada of Ukraine as the only legislative body in Ukraine whose powers include the adoption of laws»».

The Constitutional Court of Ukraine supports this position, in particular in its Decision of 28.02.2018 it is stated, "the implementation of the right of legislative initiative involves not only the submission of draft laws, other acts 
to parliament, but also mandatory consideration legislative initiatives of the relevant entities.»

At the same time, the Constitution of Ukraine does not directly determine the order as a whole, but only the basic requirements for consideration of bills, amendments and proposals to them. This procedure is currently enshrined in the Rules of Procedure of the Verkhovna Rada of Ukraine, which generally corresponds to Part 5 of Article 83 of the Constitution of Ukraine concerning establishment in the Rules of Procedure of the Verkhovna Rada of Ukraine of the order of its work.

According to the Decision of the Constitutional Court of Ukraine of 28.02.2018, the process of consideration of the bill at the sittings of the Verkhovna Rada of Ukraine is a discussion and voting of the bill, proposals to it. In view of this, the discussion of the proposals to the bill, as well as the vote on their adoption or rejection are seen as integral to the implementation of the constitutional obligation of parliament to consider the relevant bills, amendments and proposals to them. After all, as the judge of the Constitutional Court of Ukraine Sergii Sas [5] emphasizes, «at certain stages of the legislative process, proposals and amendments are part of bills and are considered in the manner prescribed for bills.»

According to Part 1 of Article 152 of the Constitution of Ukraine, laws are declared unconstitutional by a decision of the Constitutional Court of Ukraine if the constitutional procedure for their consideration, adoption or entry into force has been violated. In this case, in general ignoring (lack of discussion and voting) the submitted amendments and proposals to the bill can be considered as a violation of the constitutional right of legislative initiative and, accordingly, the constitutional procedure for consideration of the bill.

The judge of the Constitutional Court of Ukraine Oleksandr Tupitsky expresses a similar opinion, namely that leaving without consideration of amendments and proposals is a violation of the right of legislative initiative as a power exercised by its subjects on behalf of the people of Ukraine and the constitutional order of work of parliament [5]. Another judge of the Constitutional Court of Ukraine Victor Kolisnik, also sees the disregard of the submitted proposals and amendments as a violation of the constitutional procedure for consideration laws and the right of legislative initiative.

As a result, the Constitutional Court of Ukraine in its Decision of 28.02.2018 explicitly calls "deprivation of the right to consider amendments and proposals to the draft law" one of the circumstances on violation by the Verkhovna Rada of Ukraine of the procedure for consideration the draft law defined by Part 1 of Article 93 of the Constitution of Ukraine.

The procedure for consideration of the draft law determined by the Rules of Procedure of the Verkhovna Rada of Ukraine in order to simplify and speed 
up the legislative process already allows for automatic rejection of subsequent proposals in case of adoption of one of the previous proposals (Part 5 of Article 45). At the same time, such a mechanism does not impede the implementation of the constitutional right of legislative initiative, observance of which is ensured by mandatory discussion and voting of the Verkhovna Rada of Ukraine on each proposal, amendment rejected by the Main Committee, if the initiator insists on it (Part 2 of Article 120, Part 1 of Article 121).

Therefore, depriving the relevant subjects the right to insist on a mandatory vote by parliament on their proposals and amendments will lead to a violation of the duty of the parliament to consider the submitted legislative initiatives, the constitutional right of the legislative initiative, and hence the constitutional basis of the procedure for consideration of the bill.

At the same time, the Rules of Procedure of the Verkhovna Rada of Ukraine do contain certain restrictions on the exercise of the right of legislative initiative, in particular the limitation of the number of proposals and amendments considered in case of application of the special procedure of consideration of the bill in the second reading (Article 119-1). The compliance of such restrictions with the understanding of the constitutional right of legislative initiative, set out in the Decision of the Constitutional Court of Ukraine of 28.02.2018, is currently quite questionable.

It should be noted that the violation of the constitutional procedure for consideration and adoption of laws does not directly depend on the fact of observance or non-compliance with the Rules of Procedure of the Verkhovna Rada of Ukraine in case when the parliament refuses to discuss and vote on amendments and proposals to bills.

Thus, taking into account the Constitution of Ukraine, decisions of the Constitutional Court of Ukraine, constitutional science and practice the decision of the parliament to consider the bill without discussion and voting for each proposal and amendment may be considered as a violation of the constitutional procedure for consideration and adoption of laws and the right of legislative initiative. This applies in particular to cases where the subjects of their initiation are deprived of the right to insist on a mandatory vote by parliament on such proposals and amendments.

\section{References:}

1. The Constitution of Ukraine: Law of Ukraine of 28.06.1996 № 254к/96VR. Bulletin of the Verkhovna Rada of Ukraine. 1996. № 30. Art. 141.

2. On the Rules of Procedure of the Verkhovna Rada of Ukraine: Law of Ukraine of 10.02.2010 № 1861-VI. Official Bulletin of Ukraine. 2010. № 12. Art. 565. 
3. Kravchenko V. V. Constitutional law of Ukraine: textbook. 6th edition, corrected and add. Kyiv: Attica, 2007. P. 302.

4. Topolyanska T. O. Constitutional-procedural bases of realization of the right of legislative initiative: abstract of the dissertation ... of the candidate of legal sciences: 12.00.02. Kyiv, 2009. P. 6, 13.

5. Decision of the Constitutional Court of Ukraine of 28.02.2018 № 2-r/2018. Official Bulletin of Ukraine. 2018. № 37. Art. 1315.

DOI https://doi.org/10.30525/978-9934-26-148-0-16

\title{
КОНСТИТУЦЙНА РЕФОРМА В КОНТЕКСТІ КОНСТИТУЦЙНОГО ПРАВА УКРАЇНИ ЯК ВИМОГА ЧАСУ
}

\author{
Калініченко О. Ф. \\ кандидат юридичних наук, дочент, доцент кафедри права \\ Київського кооперативного інституту бізнесу і права \\ м. Київ, Украӥна
}

Розбудова права при модернізації і розвитку освіти повинна набути випереджального безперервного характеру, гнучко реагувати на всі процеси, що відбуваються в Україні та світі. Підвищення якісного рівня освіти має бути спрямовано на забезпечення економічного зростання держави та розв'язання соціальних проблем суспільства, дальше навчання і розвиток особистості. У цьому сенсі наука конституційного права $\epsilon$ вченням про методи, їх систему та принципи, а також порядок їх застосування при дослідженні явищ конституційно-правового буття, які становлять предмет відповідної юридичної науки.

Юридичні аспекти данної теми розглядалися в працях В. Сіденко, Р. Лукіч, Д. Керімов, Б. Кінаш, С. Гусарєв, А. Олійник, О. Слюсаренко, Е. Темнов, І. Кондратьєв, О. Копиленко, В. Кафарський, П. Добродумова, В. Кампо, А. Крусяна, О. Мучніка, М. Орзіха, В. Селіванова, Ю. Шемшученка, О. Ющика та ін. [1, с. 8].

Реалізація етапів конституційної реформи вимагає якісно нового формування системи права, оскільки іiі нинішній стан не сприяє зростанню соціальної захищеності й безпеки громадян держави. По-перше, в її межах не створено дієвих інструментів і механізмів, які дали б змогу повністю реалізувати наявні права суб'єктів суспільних відносин, що мають бути відображені в позитивному праві. По-друге, відсутні гармонійні взаємозв'язки між чинними нормативно-правовими актами різних рівнів, які покладені в основу правової системи держави, 